\title{
DEVELOPMENT OF BASIC GYMNASTICS COURSE TEXTBOOKS FOR STUDENTS OF PHYSICAL EDUCATION STUDY PROGRAM
}

\author{
Citra Azhariat Malasari ${ }^{*}$, Pasha Erik Juntara ${ }^{2}$ \\ 1,2 Physical Education, Faculty of Teacher Training and Education, Universitas \\ Muhammadiyah Kotabumi, Lampung, Indonesia
}

\section{Article Info \\ Article History : \\ Received : February 2021 \\ Revised : February 2021 \\ Accepted : March 2021 \\ Available online : March \\ 2021}

\section{Keywords :}

Basic Gymnastics, Coursebook,

\begin{abstract}
The purpose of this research is to develop coursebooks for basic gymnastics courses for students of the Physical Education Study Program, Muhammadiyah University Kotabumi. This research method uses the Borg and Gall development procedure which consists of 10 steps. But in this research development research does not use all of it but only with 7 steps, that is: 1) needs analysis, 2) product manufacture, 3) product validation, 4) small group trials, 5) product revision stage I, 6) large group trials, 7) product revision stage II. The result of this study are the results of the validation of material experts with the overall validation mean of $87.85 \%$, validation results from media and design experts with a minimum score of 27 , maximum score of 108 , the result score is 97 with a percentage of $89.81 \%$, Results of the Assessment Phase I Trial (small group) with a percentage of $91.11 \%$, Results of the Phase II Trial Assessment (large group) with a percentage result of $81.08 \%$. Based on the result of data analysis, it can be concluded that the basic gymnastics textbook product is suitable for use by students of the FKIP UMKO physical education study program.
\end{abstract}

\begin{tabular}{llr}
\hline Corresponding address & : Perumahan Pesona Natar Residence Kec. & ISSN 2685-6514 (Online) \\
& Natar Kab. Lampung Selatan Lampung & ISSN 2477-331X (Print) \\
*Corresponding email & $:$ citra.ciyus@ gmail.com &
\end{tabular}




\section{INTRODUCTION}

In an effort to realize a fair and prosperous society the Indonesian government conducts development in all fields, including one of them is development in the field of education and sports. Development in the field of education aims to create quality Human Resources (HR), namely human resources that are knowledgeable, have skills, healthy physical and spiritual, and have a commendable attitude and behavior. While development in the field of sports aims to improve freshness and physical health, discipline, sportsmanship, achievements, and so on. Development is a programmed effort that is carried out continuously in order to maintain and improve the standard of human life both physically and mentally (Prasetyo 2015)

According to Husdarta in Setiyawan (2019), the term sport is not used in narrow competitive sports because the definition is not only an organized and unofficial set of physical activities that appear mostly in sports but also in basic forms such as gymnastics and physical fitness training. The development of sports today has made a positive contribution to improving public health. Health is very important for humans, because without good health every human being will find it difficult to carry out their daily activities. In addition, sports can also scent the name of the nation in the international world. This shows that coaching in the field of sports can not be ignored because it has a very large role in realizing the ideals of national development. Sport coaching is something that cannot stand alone, therefore sports coaching must be carried out properly so that in national development it has a very important role (Widowati 2015)
The development of sports has the scope to carry out a training, as stated in article 17 it is explained that the scope of sports includes activities, a) educational sports, b) recreational sports, and c) achievement sports (Okilanda 2018). One of the sports scopes organized through a process education is sports education. Educational sports are physical education and sports which are carried out as part of a regular and continuous educational process to gain knowledge, personality, skills, health and physical fitness (Lauh 2016).

Muhammadiyah Kotabumi University is the only university in Kotabumi, precisely in North Lampung Regency, Lampung Province. UMKO consists of 4 Faculties and 11 study programs that have been accredited by BAN PT, including the physical education study program. Later it is hoped that graduates can transfer the knowledge that has been obtained from the lecture process. One of the subjects that must be followed by students in the Education Study Program Physical namely basic gymnastics. According to Paject in Titting, Fellyson, Hidayah, Taufik, Pramono (2016), explains "Gymnastics requires a great diversity of movements: transition from dynamic and static elements and vice versa, frequent changes of the body position in space ".

The term gymnastics originates from the English "Gymnastic" in the original language is a loanword from the Greek "Gymnos" which is means naked, while the goal of Gymnastics is increasing endurance body, strength, flexibility, agility, coordination, as well as body control (Widowati and Rasyono 2013). Cholid et al. (2020) explain, Basic Gymnastics is a movement gymnastics and a wide range of movements involves elements of strength, flexibility, balance and coordination elements. Hidayat in Sitepu, Nasution, and Ibrahim (2019) 
argues that gymnastics is a body exercise that is deliberately selected and constructed, carried out consciously and planned, systematically arranged with the aim of increasing physical fitness, developing skills and instilling mental values of spirulina. According to Daryanto in Wahyu Heny Kartika Sari, Tatok Sugiarto (2016), Gymnastics is "exercise with certain movements, such as stretching, moving, and stretching limbs". Meanwhile, according to Prasetyo (2015) "gymnastics is a sport that requires flexibility and good coordination between limbs". Based on the above statement, it can be concluded that gymnastics is an activity that relies on physical activity that is useful for developing physical components and mobility that are arranged systematically and planned to achieve a certain goal.

Based on observations and observations on the implementation of basic gymnastics courses in the Physical Education Study Program of Muhammadiyah University Kotabumi conducted, researchers found several sources of problems in learning basic gymnastics courses, namely: 1) students do not have a basic gymnastics course textbook so that in the learning process, especially psychomotor learning students find it difficult to perform motion skills, 2) in cognitive learning students feel bored because they can only get information from lecturers so that it invites lack of enthusiasm in students, 3) various other conditions that do not support the learning process.

Another basis for the implementation of basic gymnastics course textbooks is through the analysis of the needs of researchers through the filling of questionnaires distributed to 14 students of the Physical Education Study Program of Muhammadiyah University Kotabumi. From the data obtained the following conclusions: (1) student majority have problems about the absence of teaching books prepared by lecturers so that students feel difficulty in learning,(2) the majority of students in attending basic gymnastics lectures, especially when demonstrating imperfect skills, (3) the majority of students agree with the holding of teaching books in accordance with basic gymnastics courses. While the results of needs analysis with lecturers do not have a selfmade teaching book.

Basic gymnastics courses that contain pure knowledge about the process of gymnastics exercises in addition to serving as a basic science in training and training also contribute in supporting the capacity of graduates when becoming a teacher in school, especially in school there are also extracurricular activities in the field of sports groups (Sitepu et al. 2019). Basic gymnastics courses are more dominant in learning motion skills so that some lecturers do not attach importance to basic gymnastics learning in terms of cognitive, this will impact students not gaining knowledge, therefore in learning variations of learning are needed so that students in practicing psychomotor more smoothly and the movement is correct. Therefore, it is necessary to have a teaching book as a guide and also the handle of a lecturer to provide learning. Stated that learning using textbooks can make it easier learning process so as to help the achievement of participant competence completeness students.

Febrianto and Puspitaningsih (2020) said that the existence of textbooks as a medium and or source of student learning in lectures are essentially to make it easier for them to learn. Be known together that the learning process occurs both directly and indirectly. Learn directly means that students interact with lecturers. Meanwhile, learning is indirect meaning that students actively interact 
with media or other learning sources support lectures. According to Aris and Mu'arifuddin (2020), textbooks are one of the supporting media for a lecturer in providing knowledge knowledge to students.

This teaching book is expected to be a solution to basic problems related to the lack of availability of basic gymnastics learning resources as well as the development of teaching materials for students of physical education study program FKIP UMKO can help them in attending lectures. The products produced in this study are in the form of basic gymnastics teaching books. Surahman and Yeni (2019) explain that textbooks provide great benefits in activities teaching and learning because in this case textbooks help students in solve the problem.

\section{METHODS}

This type of research is Research \& Development or development research that refers to the concept of Borg and Gall dalam Surahman and Yeni (2019), This study has produced results and tests the effectiveness of products that have been made by researchers. The purpose of the implementation of this research is not to test the theory or formulate but in this case to develop effective results to be used for universities and other institutions. The subject of the study was a physical education student. The test subjects were 14 students. The development of research does not use entirely but only with 7 steps namely 1) needs analysis, 2) product creation consisting of the preparation of material preparation, interactional, books, and evaluation tools, 3) product validation consisting of media experts, learning experts, 4) small group trials using subjects of 6-12 people, interview data, observation, and kousioner collected and analyzed, 5) revision of phase I products, 6) large group trials using subjects 30100. 7) revision of product phase II.

The poll assessment refers to the Likert scale with 4 choices of answers. The answer options are 4, 3, 2, 1. For expert validation sheets of media and learning design whose assessment indicators include on the feasibility of kegrafikan consists of a) book size b) book cover design, and c) the design of the contents of the book consisting of paragraph layout, images, and colors. As for student response sheets obtained data from individual trials, small group trials, and large group trials that include; presentation of materials and benefits. This development research uses descriptive percentage data analysis techniques to help the processing of the value of the questionnaire obtained from the dissemination of questionnaires to learning media experts, learning experts, and students of the Physical Education Study Program FKIP Universitas Muhammadiyah Kotabumi.

\section{RESULT}

The results of this study began with the analysis of needs, validation of learning materials experts, validation of media and design experts, trials of stage I (small groups), trials of phase II (large groups). The needs analysis was obtained from the interview of researchers with the Head of The Study Program of FKIP UMKO and researchers also conducted an analysis of the needs obtained from students who attended basic gymnastics courses in the form of questionnaires of a book needs developing. The results of the needs analysis can be seen in the following table. 
Table 1. Needs Analysis

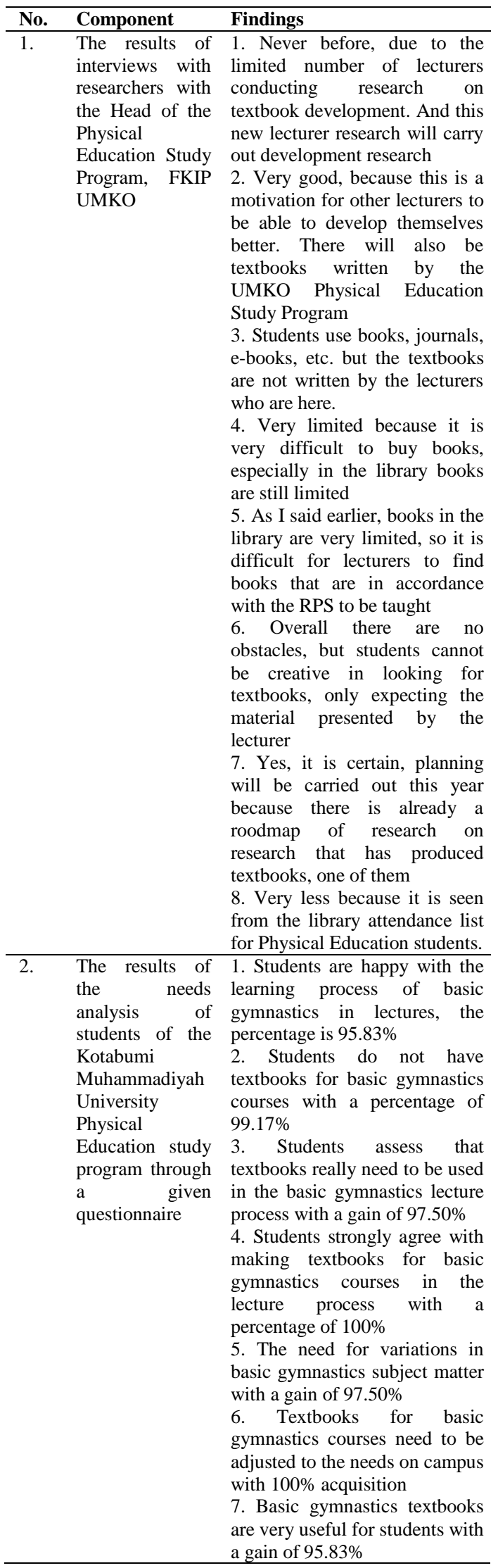

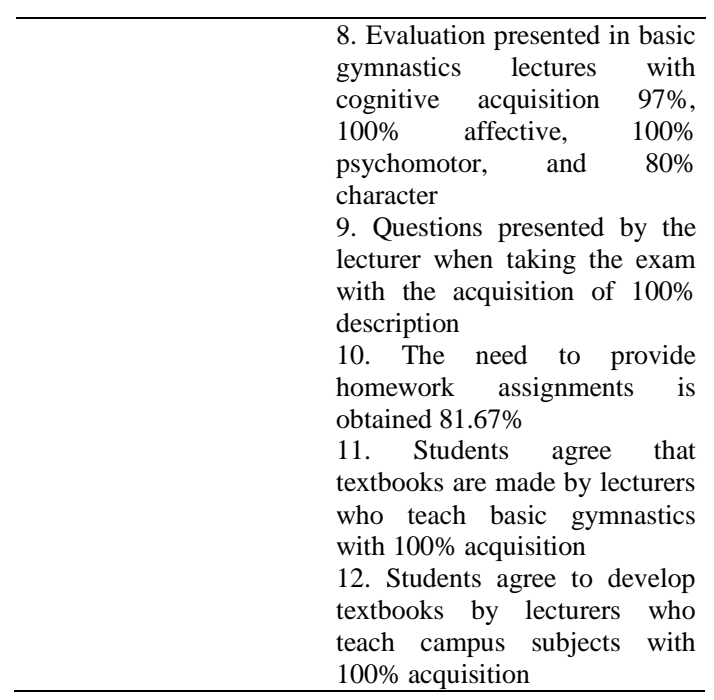

Source: 2020 research data

Table 2. Data evaluation of media and design experts

\begin{tabular}{ccccccc}
\hline No Expert & $\begin{array}{c}\text { Min } \\
\text { Score }\end{array}$ & $\begin{array}{c}\text { Max } \\
\text { Score }\end{array}$ & $\begin{array}{c}\text { Result } \\
\text { score }\end{array}$ & Percentage & $\begin{array}{c}\text { Validity } \\
\text { Level }\end{array}$ \\
\hline & & & & & & $\begin{array}{c}\text { Very } \\
\text { valid, }\end{array}$ \\
& & & & & & $\begin{array}{c}\text { usable } \\
\text { but }\end{array}$ \\
1 & $\begin{array}{c}\text { Media } \\
\text { and } \\
\text { Design }\end{array}$ & 27 & 108 & 97 & $89,81 \%$ & $\begin{array}{c}\text { needs a } \\
\text { small } \\
\end{array}$ \\
& & & & & \\
& & & & & \\
& & & & & \\
\hline
\end{tabular}

Based on table 2 above which is the validation of media and design experts with a minimum score of 27 , a maximum score of 108 , a yield score of 97 with a percentage of $89.81 \%$ with the validity level is Very Valid, can be used but needs a small revision. In the opinion of Prihatmojo and Rohmani (2020) design revisions were made to correct deficiencies in the aspects being assessed.

Validation of learning materials is done by two lecturers who teach basic gymnastics courses, namely: 1) Hilda Oktri Yeni, S.Pd, M.Pd as Lecturer of Physical Education Health and Recreation Karimun University, 2) Africo Ramadhani, M.Pd Lecturer of Physical Education University of Muhammadiyah Kotabumi. The results of data validation conducted by 2 lecturers in basic 
gymnastics learning materials are as follows:

Table 3. Material Expert Evaluation Result Data

\begin{tabular}{|c|c|c|c|c|c|c|}
\hline $\begin{array}{c}\text { Exper } \\
t\end{array}$ & $\begin{array}{c}\text { Assessed } \\
\text { Aspects }\end{array}$ & $\begin{array}{c}\text { Min } \\
\text { Score }\end{array}$ & $\begin{array}{l}\text { Max. } \\
\text { Score }\end{array}$ & $\begin{array}{c}\text { Resul } \\
\mathbf{t} \\
\text { score }\end{array}$ & $\begin{array}{l}\text { Per } \\
\text { cent } \\
\text { age }\end{array}$ & $\begin{array}{l}\text { Validity } \\
\text { Level }\end{array}$ \\
\hline \multirow{4}{*}{$\begin{array}{l}\text { Learni } \\
\text { ng } \\
\text { Mater } \\
\text { ials } \\
\text { Exper } \\
\text { ts 1 } \\
\text { and } 2\end{array}$} & $\begin{array}{l}\text { Accuracy } \\
\text { and } \\
\text { Correctne } \\
\text { ss of } \\
\text { Materials } \\
\text { (Content } \\
\text { Feasibility } \\
\text { ) } \\
\end{array}$ & 42 & 168 & 149 & $\begin{array}{l}88,6 \\
9 \%\end{array}$ & $\begin{array}{l}\text { Very } \\
\text { Valid, } \\
\text { usable } \\
\text { but } \\
\text { needs a } \\
\text { small } \\
\text { revision }\end{array}$ \\
\hline & $\begin{array}{l}\text { Learning } \\
\text { Support } \\
\text { Materials } \\
\text { (Presentatio } \\
\mathrm{n} \\
\text { Feasibility) }\end{array}$ & 28 & 112 & 100 & $\begin{array}{l}89,2 \\
9 \%\end{array}$ & $\begin{array}{l}\text { Very } \\
\text { Valid, } \\
\text { usable } \\
\text { but } \\
\text { needs a } \\
\text { small } \\
\text { revision }\end{array}$ \\
\hline & $\begin{array}{l}\text { Language } \\
\text { Assessme } \\
\text { nt }\end{array}$ & 26 & 104 & 89 & $\begin{array}{c}85,5 \\
8 \%\end{array}$ & $\begin{array}{l}\text { Very } \\
\text { Valid, } \\
\text { usable } \\
\text { but } \\
\text { needs a } \\
\text { small } \\
\text { revision }\end{array}$ \\
\hline & \multicolumn{2}{|c|}{ Average } & & & $\begin{array}{l}87,8 \\
5 \%\end{array}$ & $\begin{array}{l}\text { Very } \\
\text { Valid, } \\
\text { usable } \\
\text { but } \\
\text { needs a } \\
\text { small } \\
\text { revision }\end{array}$ \\
\hline
\end{tabular}

Based on table 3 above, the validation results of learning material experts obtained the results of the overall validation average of $87.85 \%$ with the validity level is very valid, can be used but needs a small revision.

The trial of phase I (small group) in students of FKIP UMKO program was conducted with the number of students as many as 6 people, as for the results of data validation conducted as follows:

Table 4. Phase I Trial Result Data (Small Group)

\begin{tabular}{cccccc}
\hline \multirow{2}{*}{$\begin{array}{c}\text { Compone } \\
\text { nts }\end{array}$} & $\begin{array}{c}\text { Min } \\
\text { Scor }\end{array}$ & $\begin{array}{c}\text { Scor } \\
\text { Scor }\end{array}$ & Resul & Percentag & Validity \\
& e & e & score & e & Level \\
\hline
\end{tabular}

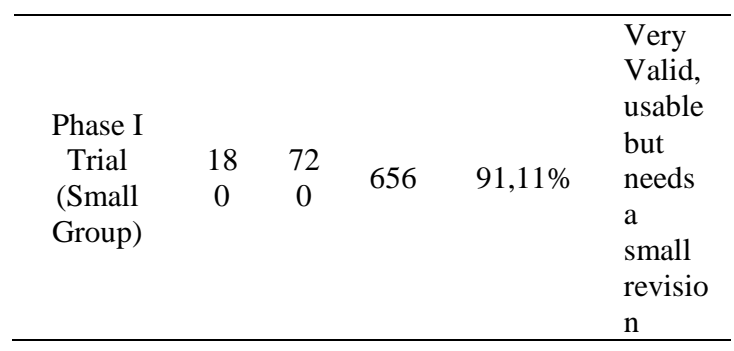

Based on table 4 above, the validation results of phase I trial (small group) with a minimum score of 180 , a maximum score of 720 , a result score of 656 with a percentage of $91.11 \%$ with a validity level is very valid, can be used but needs a small revision.

The trial of phase II (large group) in students of FKIP UMKO study program was conducted with the number of students as many as 30 people, as for the results of data validation conducted as follows.

Table 5. Phase II Trial Result Data (Large Group)

\begin{tabular}{|c|c|c|c|c|c|}
\hline $\begin{array}{c}\text { Compo } \\
\text { nents }\end{array}$ & $\begin{array}{c}\text { Min } \\
\text { scor } \\
\text { e }\end{array}$ & $\begin{array}{l}\text { Max } \\
\text { score }\end{array}$ & $\begin{array}{l}\text { Result } \\
\text { score }\end{array}$ & Percentage & $\begin{array}{l}\text { Validit } \\
\text { y Level }\end{array}$ \\
\hline $\begin{array}{l}\text { Phase } \\
\text { II Trial } \\
\text { (Large } \\
\text { Group) }\end{array}$ & $\begin{array}{c}90 \\
0\end{array}$ & $\begin{array}{c}360 \\
0\end{array}$ & 3279 & $81,08 \%$ & $\begin{array}{l}\text { Very } \\
\text { Valid, } \\
\text { usable } \\
\text { but } \\
\text { needs a } \\
\text { small } \\
\text { revision }\end{array}$ \\
\hline
\end{tabular}

Based on table 5 above, the validation results of phase II trial (large group) with a minimum score of 900 , a maximum score of 3600 , a result score of 3279 with a percentage of $81.08 \%$ with a validity level is very valid, can be used but needs a small revision.

\section{DISCUSSION}

Based on the analysis, the validation result from the material expert with the overall validation average result is $87.85 \%$ with a very validity level. , the validation results of media and design 
experts with a minimum score of 27 , a maximum score of 108 , a result score of 97 with a percentage of $89.81 \%$ with a very validity level., The results of the Trial Assessment phase I (small group) with a percentage result of $91.11 \%$ with a validity level is very valid., the Results of the Trial Assessment phase II (large group) with a percentage result of $81.08 \%$ with a validity level is very valid. Based on the results of the above research the whole basic gymnastics textbook developed is good and feasible and can used after revisions in accordance with the suggestions and comments of material experts and experts media and design, this is in accordance with the opinion according to Fidiastuti \& Rozhana in Sanusi, Surahman, and Yeni (2020), the results of development products in the form of textbooks that have been revised based on comments and validator suggestions aim to improve textbooks, so that the use of textbooks becomes more efficient, effective and communicative to readers, while paying attention to goals compilation of textbooks.

The development of textbooks for basic gymnastics courses for students of the FKIP UMKO physical education study program can be used by students for the learning process of basic gymnastics and also for gymnastics lecturers as guidelines for the preparation of lecture teaching materials. The use of textbooks is needed by students to be able to study the entire learning material, and students can learn more detailed theories by reading this textbook, this is in line with the opinion of Surahman and Yeni (2019) which states that textbooks provide great benefits in learning activities. teaching because in this case textbooks help students in solving problems. Therefore a student must have a textbook to be able to solve learning problems in theory so that students have good abilities in learning materials, especially in basic gymnastics courses.

\section{CONCLUSION}

Based on the results of research on the development of basic gymnastics teaching books for students of the study program FKIP UMKO has produced a product of teaching books that can already be used by students on basic gymnastics courses. This product has been validated by material experts and media and design experts as well as in students with phase I trials (small groups) and phase II trials (large groups) with a validity level that is very valid, can be used but needs a small revision.

\section{ACKNOWLEDGEMENT}

We would like to thank the Directorate General of Strengthening Research and Development of the Ministry of Research, Technology and Higher Education who has provided a very useful research fund in this research, to the Rector of Muhammadiyah University Kotabumi, Dekan of FKIP Universitas Muhammadiyah Kotabumi, Chairman of PPPM University of Muhammadiyah Kotabumi, Fadli Surahman, S.Pd, M.Pd, Hilda Oktri Yeni, S.Pd, M.Pd, and to all parties who have helped until this paper is completed.

\section{REFERENCES}

Aris, Tria, and Moh Ali Mu'arifuddin. 2020. "Pengembangan Buku Ajar Bola Basket Untuk Mahasiswa." Jendela Olahraga 5(2):62-69.

Cholid, Abd, Program Magister, Pendidikan Jasmani, Pascasarjana Universitas, Pgri Adi, and Buana Surabaya. 2020. "Pengembangan Model Pembelajaran Kerjasama Tim Dalam Efektivitas Penguasaan Gerakan Senam Dasar Prestasi Volume 1 Nomor 1 Tahun 
2020 | 1 Journal STAND: Sports and Development A . Model Pembelajaran Proses Pembelajaran Akan Berhasil Jika Ditentukan Oleh Be." 1:1-8.

Febrianto, Rohmat, and Flora Puspitaningsih. 2020. "Education Journal: Journal Education Research and Development." Journal Education Research and Development 4(1):1-18.

Lauh, Whalsen Duli Agus. 2016. "Dimensi Olahraga Pendidikan Dalam Pelaksanaan Penjasorkes Di Sekolah.” Jurnal Pendidikan Olahraga 3(1):83-93.

Okilanda, Ardo. 2018. "Revitalisasi Masyarakat Urban/Perkotaan Melalui Olahraga Petanque." Journal Halaman Olahraga Nusantara 1(1):86-98.

Prasetyo, Yudik. 2015. "Kesadaran Masyarakat Berolahraga Untuk Peningkatan Kesehatan Dan Pembangunan Nasional." Medikora 11(2):219-28. doi: 10.21831/medikora.v11i2.2819.

Prihatmojo, Agung, and Rohmani. 2020. "Pengembangan Model Pembelajaran Kooperatif Berbasis Literasi Berkarakter Dengan Game WHO AM I." Journal of Educational and Instruction 3(2):312-21. doi: https://doi.org/ 10.31539/joeai.v3i2.1608 PENGEMBANGAN.

Sanusi, Rahmat, Fadli Surahman, and Hilda Oktri Yeni. 2020. "Pengembangan Buku Ajar Penanganan Dan Terapi Cedera Olahraga." Journal Sport Area $5(1): 40-50$. doi: 10.25299/sportarea.2020.vol5(1).4761.

Setiyawan. 2019. "Visi Pendidikan Jasmani Dan Olahraga." Jurnal Ilmiah PENJAS 3(October 2013):1-224.

Sitepu, Indra Darma, Muhammad Faisal Ansari Nasution, and Ibrahim Ibrahim. 2019. "Pengembangan Bahan Ajar Senam Dasar Model Hybrid Learning Berbasis Kkni." Jurnal Prestasi 3(5):56. doi: 10.24114/jp.v3i5.13450.

Surahman, Fadli, and Hilda Oktri Yeni. 2019. "Pengembangan Buku Ajar Mata Kuliah Renang Bagi Mahasiswa Pendidikan Jasmani Kesehatan Dan Rekreasi." Journal Sport Area 4(1):218-29. 10.25299/sportarea.2019.vol4(1).2413. Titting, Fellyson, Hidayah, Taufik, Pramono, Harry. 2016. "Pengembangan Multimedia Pembelajaran Senam Lantai Berbasis Android Pada Pendidikan Jasmani Olahraga Dan Kesehatan Di Sma." Journal of Physical Education and Sports 5(2):120-26. doi: 10.15640/jpesm.

Wahyu Heny Kartika Sari, Tatok Sugiarto, Sri Purnami. 2016. "Pengembangan Pembelajaran Senam Lantai Rangkaian Sederhana Siswa Kelas VIII Di SMP Negeri 2 Ngoro Kabupaten Mojokerto." Jurnal Pendidikan Jasmani 26(1):1-15.

Widowati, Atri. 2015. "Modal Sosial Budaya Dan Kondisi Lingkungan Sehat Dalam Pembinaan Prestasi Olahraga Pelajar." Jurnal Kesehatan Masyarakat 10(2):218. doi: 10.15294/kemas.v10i2.3384.

Widowati, Atri, and Rasyono. 2013. "Pengembangan Bahan Ajar Senam Lantai Untuk Pembelajaran Senam Dasar Pada Mahasiswa Fakultas Ilmu Keolahragaan Universitas Jambi." Journal of Chemical Information and Modeling 53(9):1689-99. 